\title{
Legal Implication of the Effect of the TRIPS Agreement on the Trade Marks Law in Nigeria
}

\author{
Temitope O. Oloko (LL.B, LL.M, LL.MIP/CT LL.D) \\ Faculty of Law, Lagos State University, Lagos, Nigeria
}

doi: 10.19044/esj.2016.v12n10p140 URL:http://dx.doi.org/10.19044/esj.2016.v12n10p140

\begin{abstract}
The implication and the effects of the TRIPS Agreement in developing nations are constantly unfolding. Modern businesses use trade marks as an important public relations tool for marketing purposes. Considering the importance of the TRIPS Agreement in the trade mark regime, assessing the legal effect that the Agreement has on the law in Nigeria helps in determining the compliance of the Trade Mark Law to a large extent. The aim of this article is to identify the areas of compliance and to discuss the diversity and effectiveness of the TRIPS agreement. The article sheds light on the level of compliance of the Trade Marks Law and the expected impact. This could help in identifying the level of fulfilment of Nigeria's international trade obligation. The study contributes to knowledge by providing insights in determining the extent to which the Trade Mark Law still need reformation. The areas covered by this article are limited to service marks, well-known marks, the requirement for use, and parallel importation.
\end{abstract}

Keywords: Trade Marks, TRIPS, Parallel imports, Well-known marks

\section{Introduction}

In 2013, when MINT was conceived by O’Neil, nobody took note of the acronym. MINT means Mexico, Indonesia, Nigeria, and Turkey. However, these countries were carefully chosen for their demographic advantages and economic prospects (Boesler, 2014). Like BRIC, which was also coined by O'Neil, the economies of these countries are worthy of note. Nigeria is one of the countries among the MINT. As a result, the impact of the WTO TRIPS Agreement on its trade marks laws is of great importance.

The 2014 World Bank Report: Africa's Pulse declared Nigeria as the largest economy in Africa and one of the frontier markets in Sub-Saharan Africa, which elicits a significant part of the region's net capital flow from Foreign Direct Investment (FDI). The above assertion is evidenced by the fact that "Nigeria has seen an increase in Net Portfolio Equity inflows from a 
mere $\$ 0.5$ billion in 2009 to $\$ 10$ billion in 2012.” As robust as this looks, the issue remains that Nigeria has a large population of impoverished people. Therefore, care must be taken when viewing these statistics. Trading is one of the major occupations of most Nigerians. Accordingly, the effect of the Agreement on Trade Related Aspects of Intellectual Property Rights (TRIPS Agreement) is crucial to the daily sustenance in the country.

Trade marks have been widely used in several centuries (Groves, 1997), and in businesses as an important source identifier. Hence, this represents a valuable commercial asset. Trade marking can be said to be one of the areas of intellectual property (IP) that has been in existence in Nigeria before contact with the Europeans. Consequently, marks were used in various forms. This ranges from the identification of the place of origin of persons to their status in the society, and on animals, products, and crafts (Sodipo, 1997). Furthermore, these marks were also used in commerce by traders who marked their goods for identification of its source of origin (Sodipo, 1997, p. 39). Some of these practices are still in use till date, for instance, yams are still marked for identification based on its origin or the owner/trader.

Although, there have been no pressure from developed countries to enforce a revision of the Trade Marks Act of 1965, there is the need for protection of intellectual property rights (IPRs) based on economic and social considerations. The impact and implementation of the TRIPS Agreement in relation to trade marks has not been given much attention as copyrights and patents. Despite that, trademark laws have undergone profound changes internationally. Also, considering the recent proliferation of trade marks on consumer goods in Nigeria, it is important to examine the law in order to know how effective the law is. This is with the aim of appreciating the nature and extent of the legal obligation Nigeria has under the TRIPS Agreement.

This article offers a perspective on the protection of trade mark by undertaking a comparative examination of the trade marks provisions of the TRIPS Agreement. This is with the corresponding provision of law under the Nigerian Trade Marks Act in order to determine its compliance with the provisions of the TRIPS Agreement. This article will analyse the substantive law and regulation by exploring whether the 49-year-old Act and 47-year-old Regulation can possibly comply with the TRIPS Agreement. Also, it aims to determine its effect on the law, particularly if Nigeria has to make its laws to be compliant with the TRIPS Agreement. This article will limit its consideration to certain substantive provisions of the TRIPS Agreement. Thus, these include provisions on protectable subject matter (Article 15), protecting well-known marks (Article 16.2), the requirement of use in maintaining registration (Article 15.3 and 19.1), and parallel importation of 
grey goods and exhaustion of rights (Article 17). The rest of the paper is organised as follows: section 2 examines the recognition and reception of international law. Section 3 discusses the dynamics of transition arrangement of the TRIPS Agreement. Section 4 provides a comparative analysis of the Nigeria Trade mark law and the TRIPS Agreement, while section 5 gives the concluding remarks of this study.

\section{Recognition and Reception of International Law}

The Trade Marks Act of 1965 is the first indigenous Legislation on Trade Marks in Nigeria. Hence, it is still in the current Law. Substantially based on the UK Trade Marks Act of 1938, the 1965 Act repealed the Trade Mark Act of 1958 (Babafemi, 2007). The Trade Mark Act (TMA) came into force in 1967 when the Trade Marks Regulations Order of 1967 was instituted for the administration of the system (Sikoyo, Nyukuri \& Wakhungu, 2006). Although after the inception of the TRIPS Agreement, the Laws of the Federation of Nigeria were compiled anew. As such, the Trade Mark Acts of 1965 has now been incorporated into the Laws of the Federation of Nigeria in 2004 as contained in Chapter T13. Nevertheless, the content of the law remains the same. Accordingly, it cannot be said that there have been a review of the laws on Trade Marks in Nigeria.

Having mentioned that Nigeria still operates under the Trade Marks Acts of 1965, an examination of its comparative effect is based on the fact that there is a need to determine the stance of the legal framework of Nigeria in relation to its international obligation. The Nigerian legal structure is dualistic in nature. Thus, the reason is that the Nigerian Constitution in section 12 (1) consist of an important element which makes it clear that international treaties will only have an effect if they are domesticated. This means that any international treaty has to be passed into law by the National Assembly for it to have the effect of law contemplated in the international instrument. In addition, it is provided in the trade marks law that a Declaration can be made by the minister in the Federal Gazette to give effect to a treaty (Section 44 (5)). Therefore, this declaration made by the executive arm of government still needs to pass through the legislative arm, before it can be passed into law (Oyebode, 2003).

Section 12 (1) of the 1999 Constitution of the Federal Republic of Nigeria (as amended) has been subject to various judicial interpretation by the Supreme Court. This was done in the case of General Sanni Abacha v. Gani Fawehinmi where the issue of the supremacy of the Constitution over the African Charter on Human and Peoples Rights came up for consideration. Per Ogundare, JSC, gave a reason for its decision:

No doubt Cap.10 (The African Charter

on Human and Peoples Rights (Ratification and Enforcement) 
Act 1990) is a Statute with International flavour. Being so therefore, I would think that if there is a conflict between it and another Statute, its provision will prevail over those of that other Statute for the reason that it is presumed that the Legislature does not intend to breach an International obligation. To this extent, I agree with their Lordships of the court below that the Charter possesses 'a greater vigour and strength' than any other domestic Statute. But, that is not to say that the Charter is superior to the Constitution as erroneously.... Nor can its International flavour prevent the National Assembly or the Federal Military Government to remove it from our body of Municipal Laws by simply repealing Cap.10; nor also is the validity of another Statute necessarily affected by the mere fact that it violates the African Charter or any other Treaty for that matter.

Thus, the courts have clearly stated that the international treaty would have superiority where it is in conflicts with domestic legislation. In essence, the provision of the Nigerian Constitution only applies where there is no conflict. I doubt if the intention of the drafters is for the constitution to be side lined when it conflicts with international law. This has, however, been the position of the court as held by the Court of Appeal in Chief J.E Oshevire v. British Caledonian Airways Ltd. Furthermore, this is regarding the application of the Warsaw Convention under the Nigerian law. In addition, the court held that an international agreement which is embodied in a Covenant or Treaty is above Domestic Legislation. Also, any other domestic legislation which is in conflict with such Convention is void.

The decisions of the courts over the years have not been unanimous. The reason is based on the fact that there have also been decisions that interpret Section 12 (1) of the CFRN 1999 (as amended) as paramount. In Capital Bancorp Ltd v. Shelter Savings and Loans Ltd, it was held that 'the Constitution of Nigeria and its provisions are supreme.' Also in OloruntobaOju v. Dopamu, the Supreme Court held that 'any provision of an existing law which is in conflict with the provisions of the 1999 Constitution must be pronounced void to the extent of such inconsistency.'

These cases clearly show the inconsistences in the decisions of the courts as to whether there is a need to domesticate an international treaty. On the other hand, it takes effect once it has been accented to by Nigeria. Subsequently, this surely leaves much to be desired as to the position of the interpretation of the provisions of the Constitution.

Jurisprudentially, there seems to be no stance as to whether it is an international treaty that prevails over the domestic law, whether or not a country has ratified the treaty, or if there is a need for domestication of such treaty to have the effect of law. Basically, it seems that the application of 
international provision will be viewed from the point of view of not only seeing that justice is done, but for it to actually be done. Consequently, the Constitution is regarded as the grundnorm. The Supreme Court and all other courts derive their authority from the Constitution. Accordingly, the authority of the Supreme Court cannot be superior to the provisions of the Constitution. Therefore, this means that the pronouncement of the Supreme Court cannot supersede the provisions of the Constitution.

Flowing from the discussion above on the reception of international laws, the country stands in its obligation concerning international Agreements. In this case, the TRIPS Agreement calls for the determination of the legal effect on the domestic laws in Nigeria. Nigeria as a member of the World Trade Organisation (WTO), has agreed to certain obligations which come as a package in the WTO Agreements. Thus, this obligation includes the Agreement on Trade Related Aspects of Intellectual Property Rights. The TRIPS Agreement is part of a complex body of international law that governs trade relations between states (Taubman, 2011). The TRIPS Agreement sets standards that define what trading partners can legitimately expect from one another as on how IP is protected. One of the major revolutions in IP policy making is the adoption of the TRIPS Agreement. From the forgoing, will the provisions of the TRIPS Agreement prevail over domestic laws where there is a conflict? The answer to the above question seems to be negative. Thus, from the provision of section 1 of the Constitution which states the supremacy of the Constitution, it is clear that:

(1) This Constitution is supreme and its provisions shall have a binding force on all authorities and persons throughout the Federal Republic of Nigeria.

(2) The Federal Republic of Nigeria shall not be governed, nor shall any person or group of persons take control of the Government of Nigeria or any part thereof, except in accordance with the provisions of this

Constitution.

(3) If any other law is inconsistent with the provisions of this Constitution, this Constitution shall prevail, and that other law shall to the extent of the inconsistency be void.

\section{Dynamics of Transition Arrangement of the TRIPS Agreement}

The implication of the TRIPS Agreement in Developing Countries (DCs) has been a subject of intense and extensive debate at national and 
international levels, in different forums such as the WIPO, WHO, FAO for expert, and political bodies which include UN Commission on Human Right and Sub-Commission on the Protection and Promotion of Human Rights, as well as global bodies consisting of UNCTAD-ICTSD. Furthermore, the debate has created division amongst policy makers and commentators alike, with each side 'talking past, rather than to each other' (Yu, 2009).

The TRIPS Agreement was established to set out minimum universal standards for the protection of all areas of Intellectual Property (Copyright and Related Rights, Trade marks, Geographical Indications, Industrial Designs, Patents, Layout-Designs (Topographies) of Integrated, Circuits Protection of Undisclosed Information, Control of Anti-Competitive Practices in Contractual Licences). Also, it allows members to provide more extensive protection of IP if they so wish (WTO). The intention of the Agreement is to implement these standards globally through a WTO enforcement mechanism. Intellectual Property protection was 'married' to international trade (Pangariya, 2004) as part of a complex body of international law. This law governs relations between states on trade matters; generally, it sets the standards that define what trading partners can legitimately expect from one another in the protection of IP (Taubman, 2011). Accordingly, members at the inception of the TRIPS Agreement were required to domesticate the provisions of the Agreement. Also, they were expected to notify the TRIPS Council of the subject-matter of the Agreement that have been passed into Laws and Regulations in the implementing country (Article 63.2).

Initially, no member was obliged to apply the provisions of the TRIPS Agreement before the expiry of a general period of one year following the date of entry into force of the WTO Agreement on the $1^{\text {st }}$ of January 1995 (Article 65). Developing and least-developed countries were given a different time frame. Thus, the initial period for transition to full compliance was until 1st January 2006 (Article 65). Over the years, the transition period of the LDCs has been extended further to 1st January 2011 and 1st January 2016.

Nigeria is a developing country. In essence, it is expected that the laws should have been reviewed in compliance with its international obligations. However, this is not the case. On this basis, knowing that Nigeria has an international obligation to comply with, and the laws have not been reviewed after the initiation of the TRIPS Agreement, and in view of the lapse of the transition period, the essence of this article is to examine if the existing laws are in compliant with the TRIPS Agreement or if there is a need to review the law so that the TRIPS provisions can be transformed into Law. 


\section{The Level of Compliance of the Nigerian Trademark Laws to the TRIPS Agreement}

The implications of the content of the WTO/TRIPS Agreement are fundamental to all economies in the world. It is vital to assess the effect of the TRIPS Agreement in Nigeria. This is to enable the proper formulation of laws that could empower sustainable development. The TRIPS Agreement presents a declaration of the minimum standard of IPR to which all member countries of WTO have made a commitment to. The protection of IP has become a focus of specific attention from a developing country's perspective since the TRIPS Agreement came into force in 1995. The issues of focus depend on the country in question. Some of the focus areas for Nigeria will be discussed below.

\section{Recognising Service Marks in Nigeria}

Protectable subject matter under the TRIPS Agreement states that any sign or any combination of signs, capable of distinguishing the goods or services of one undertaking from those of other undertakings, shall be capable of constituting a trademark. Also, there is an exclusive right to prevent all third party uses without the owner's consent of goods and services. This can be seen in the course of identical or similar trade, which is likely to cause confusion on both goods and services (Article 16.1).

It is important to highlight the trade mark provisions as a background to the normative and institutional frameworks set up in the past and present for better analogy. The Trade Mark Act in Section 67 defines a mark as a device, brand, heading, label, ticket, name, signature, word, letter, numeral, or any combination thereof. In recent times, marks have been defined in other jurisdictions to include colour, scent, shape, sound, pattern, and container of goods or product packaging and any combination thereof. These inclusions have considerably increased the features of a product that can indicate source (Bently \& Sherman, 2009). As a result of increasing the margins of a mark, the courts had to tread carefully in deciding whether some of these marks can, in fact, be protected or registered.

In addition, section 67 of the Act contains the definition of a trade mark upon which the Act is to function. Thus, it was defined as:

A mark used or proposed to be used in relation to goods for the purpose of indicating, or so as to indicate, a connection in the course of trade between the goods and some person having the right either as proprietor or as registered user to use the mark, whether with or without any indication of the identity of that person, and means, in relation to a certification trade mark, a mark registered or deemed to have been registered under section 43 of this Act. 
It is worthwhile to state that this definition has been criticised by several scholars over the years as complex, not easily understandable, obscure, and restrictive due to the fact that it is archaic (Oguamanam, 1998; Mordi, 2011; and Oyewunmi, 2007). Furthermore, one of the major criticisms was that trade marks 'may only be affixed to goods traded by a proprietor' (Mordi, 2011). On the other hand, the Act blindly followed the UK Act of 1938, which was not user friendly (Shyllon, 2003). Nevertheless, it has been the working definition for trade marks for 39 years.

Clearly and as noted by Mordi, “an examination of the Act reveals that it has not incorporated in its provisions and classification, the registration and protection of trade marks in relation to services”. The learned author backed up his claim and assertion by positing that a glance at the Trade Marks Act and the Trade Marks Regulation on classification of goods give some idea that services are not protected under the Trade Marks legal regime in Nigeria. However, this position is the same even though there has actually been a change.

Generally, a service mark is registered specifically in relation to services. The absence of the ability to extend trademark protection to service mark had been a source of concern to many service providers both locally and internationally. Thus, it became pertinent for Nigeria to move with the tide of globalization to protect the other half of trademark. In Africa, not to mention the world prior to 2007, there was only a hand full of African countries which did not provide for the protection of service marks, namely: Gambia, Malawi, Nigeria, Sierra Leone, Uganda, and Zambia (Kayode, 2003). Currently, only Malawi, Sierra Leone, and Zambia do not protect service marks in Africa.

In 1990, the Law Reform Commission attempted to review other aspects of intellectual property after the revision of the Copyright Act in 1988 (Oguamanam, 1998, p.63). Subsequently, this effort did not culminate in a review of the laws although there was still a gapping need for the review of the law. This was particularly to include the protection of service marks. After several calls from different quarters for service marks to become protectable, and the need for the distinction of services provided by different corporation (Oguamanam, 1998 p.70), it was stated that the protection of service marks had become a necessity. Accordingly, in April 2007, through an executive fiat, the Federal Minister of Trade and Commerce acting in accordance with the enabling law in sections 42 and 45(1)(b) of the Act enabled the registration of 'service marks' (Okorocha, 2007, Taiwo, 2009 and Mordi, 2011). The executive fiat incorporated the Nice classification of goods in the Fourth Schedule of the Trade Marks Regulations. Thus, this thereby extends the classes of goods to include services in classes 35-45 in the Nice classification. Although, presently, service marks can be registered 
and protected, there is a need for this to be reflected in the Act as it is the first place that would be looked at for guidance. As it stands, the requirement of the protection of goods and services is complied with the result of the Ministerial Declaration of 2007.

\section{Protecting Well-known Marks}

The protection of well-known marks stems from the fact that the world has become a global village, and local traders and businesses tends to take advantage of the reputation of well-known marks (Mostert, 1997). Article 6(b) of the Paris Convention on the protection of well-known Trademark (Stoll, Busche, \& Arend, (Eds) 2009), provides that a competent authority in the country of registration may refuse, cancel the registration, prohibit the use of a trademark which constitutes a reproduction, an imitation, or a translation that is liable to create confusion where the legislation so permits or at the request of an interested party. Additionally, the mark must be used on identical or similar goods by a person entitled to the benefits of the Convention. Article 16.2 of the TRIPS Agreement extends similar rights to well-known service marks. In determining whether a trademark is well-known, members shall take into account the knowledge of the trademark in the relevant sector of the public. This includes knowledge obtained as a result of the promotion of the trademark. According to Bodenhausen, the purpose of the provision under consideration is to: ... avoid the registration and use of a trade mark, liable to create confusion with another mark already well known in the country of such registration or use. Although the latter well-known mark is not or not yet protected in that country by a registration which would normally prevent the registration or use of the conflicting mark (Ladas, 1951).

The justification for the protection given to such marks stems from the fact that such use results to unfair competition. Also, it may be prejudicial to the interest of the public who were deceived (Bodenhausen, 2007).

Another notable issue in Article $6 b$ is the protection of unregistered marks that qualifies as 'well-known' in a member nation (Reiss, 2010). It has been observed that a trademark may be well-known in another country before its registration even before it is used in such countries due to advertisement in other countries. Consequently, whether a trademark is wellknown in a country may have to be resolved by a competent administrative or judicial authority (Bodenhausen, 2007). In the South African case of McDonald's Corporation v Joburgers Drive-Inn Restaurant (PTY), a number of McDonald's trade mark had been registered in South Africa with respect to a variety of goods and services relating to their fast food services and 
foodstuffs. However, there were no McDonald's outlets in operation in South Africa as at the time of instituting this study. Joburgers Drive-Inn Restaurant proposed to open a chain of McDonald's fast food outlets selling Big mac, McMuffins, Egg McMuffins etc. Thus, the Supreme Court of South Africa held that the mark called McDonald's was entitled to protection as a "wellknown trademark" under Article 6(b) of the Paris Convention. This was despite having never been used at that time within South Africa.

The protection of well-known marks is to avoid the protection of conflicting marks getting registered at the detriment of the well- known mark (UNCTAD-ICTSD, 2005). What is a well-known trade mark is subject to determination of various factors such as the relevant sector of the public and knowledge obtained as a result of the promotion of the trademark in the Member State (WIPO, 2000). Therefore, this can be interpreted that a mark must at least be in use in a WTO Member state for it to be recognised as well-known. A mark that is well-known in South Africa may not be regarded as well-known in Nigeria. For example, LUCKY STAR is a well-known trade mark used on Pilchards in South Africa, but that trade mark and product is not readily available in the Nigerian market. Therefore, it is unknown in the Nigerian market. Furthermore, for it to get protection in Nigeria, the relevant sector of the public can only have knowledge of it due to the promotion of its trademark.

Unfortunately, in Nigeria, there is no provision for the protection of well-known trade marks. However, well-known marks can be protected as 'defensive marks' (Section 32). Section 32 of the Trade Marks Act implies that a registered proprietor of a trademark may apply for the registration of the trademark in respect to any goods that is already registered in his name. Also, other goods or classes are considered as a defensive trade mark. The trademark is registered for goods which the proprietor has no intention of using. In addition, variation or similar marks to the registered trademark which is in use can be registered. The purpose of this registration is to create a defensive perimeter around the registered trademark (Danish Patent and Trademark Office, 2010). Although, well-known marks are not expressly protected, the defensive registration of well-known invented words gives well known-marks the necessary protection required under the Paris Convention and the TRIPS Agreement. It should, however, be noted that although the Act refers to only goods, services are now covered under the law. The criteria for the protection of well-known marks are well established in other jurisdiction such as the United Kingdom, Canada, United States, and Japan.

The protection of the reputation of well-known marks extends protection of well-known marks to non-identical and non-similar goods and services alike (Article 16.3). The Nigerian Trade Marks Act has a similar 
provision. However, by allowing the registration of trade marks on different goods and other variations or similar marks on different goods may create a form of dilution of the mark. Thus, since the marks are not used in commerce, only a self-dilution of the mark may not occur.

Although, well-known marks may be protected under section 32 of the TMA by defensive registration of the mark, there is a need to specifically protect well-known mark. This protection should be done not as defensive marks because defensive registration unnecessarily clogs up the trade marks database with useless as well as useful trade marks. Furthermore, the system of defensive trademark registration can lead to trademark clutter especially in an automated system of registration. Trade mark clutter is described in a United Kingdom Intellectual Property Office Report as 'registers containing such a large number of unused or overly broad trade marks that the costs of creating and registering new marks substantially increase for other applicants (Intellectual Property Office (IPO), UK, 2012), thereby constituting an obstacle to new marks (Smyth, 2010)

According to the report, it is 'mainly a problem of absence of housekeeping mechanisms', (IPO 2012) which is typical of what is happening in Nigeria. It is important that Nigeria should amend its laws to protect well-known marks of Nigerian proprietors and other countries that Nigeria has treaty obligation. However, registration of well-known trade marks should be done with restraint. Firstly, the requirement of use in Nigeria needs to be enforced. Thus, proposed use should not be accepted for registration. For a mark to be well-known in Nigeria, the extent to which the mark is used in the relevant sector of the public, as well as the promotion of the trade mark in Nigeria must be taken into account.

\section{The Requirement of Use}

Article 15.3 of the TRIPS Agreement gives flexibility to member states by allowing them to determine whether or not to make registration dependent on use. The article further provides that the "actual use of a trademark shall not be a condition for filing an application for registration." In Nigeria, registration of a trademark does not depend on whether the mark is actually used or not. Therefore, a mark may be registered if it has been in use or it is still proposed to be used by the applicant (section 18). This goes against the common law position where a trademark owner can only acquire registration rights only after the mark was actually used in commerce. Notably, trademark rights are acquired through registration of the mark in Nigeria. Accordingly, issues of the use of a trade mark would not become an issue until the mark has been registered. According to section 31(2) (b), where a mark has been registered mala fide without any intention of using 
the mark on goods and there has not been a bona fide use of the mark on goods, an application can be brought to remove it from the register if five years or longer has elapsed from the date of registration, and if the trade mark has not been used in compliance with the provision of the TRIPS Agreement. Removal from the register based on non-use is not automatic. Therefore, it must be shown that such non-use was not due to special circumstances in the trade and not a deliberate intent not to use or abandon the trade mark (Section 31(4)). This requirement of use is to ensure that the trademark register does not become clogged with unused trade marks that prevent registration of other trade marks which are in use or intended to be used (Bodenhausen, 2007, p.75).

Subsequently, article 15.3 seems to imply that the application for trade mark registration will be open for three years. It is believed that the intent of this provision is that such marks shall not be removed from the register after allowance of the application for registration of the mark solely on the ground that it has not been used within three years.

Although, the TRIPS Agreement does not require the use of a trade mark before registration, some countries such as the US still requires a trademark to be used in commerce or have a bona fide intention to be used in commerce (see also 15 U.S.C. 1051).

As pointed out by Kur, the criterion for the use of a mark is important and directly proportional to the function as the concept upon which trade marks are founded (Kur, 2008). In summary, the propose to use or intention to use does not meet the purpose upon which the theory of a trade mark is created. Put succinctly by an EU Directive, the purpose of the use requirement is set out as follows:

In order to reduce the total number of trade marks registered and protected... and, consequently the number of conflicts which arise between them, it is essential to require that registered trade marks must actually be used, or if not used, be subject to revocation (Recital 9, the Harmonisation Directive 2009/25)

In conclusion, the Nigerian law is clear in this regard that:

[n]o application for the registration of a trade mark in respect of any goods shall be refused, nor shall permission for such registration be withheld, on the ground only that it appears that the applicant does not use or propose to use the trade mark (Section 35(1)).

The first sentence of article 15.3 is an optional provision which countries may adopt if they deem fit. Accordingly, Nigeria's position is not at variance with what is expected under the TRIPS Agreement.

Therefore, the requirement for use in article 19.1 deals with the maintenance of registration. The value of a trade mark hinges on its use in 
the course of trade concerning the goods or service for which it is registered. As discussed above, under the Act, a trade mark is cancelled only after a continuous period of five years or longer of non-use has elapsed. During this period, the registered trade mark was not put to genuine use in Nigeria by the proprietor in relation to the goods or services for which it is registered, and there are no proper reasons for non-use of those goods by the proprietor (Section 31). Use of a trade mark can also be used by a registered user (Section 33 (3)). A registered user, being a person other than the proprietor of a trade mark, is someone who has been statutorily declared and authorised by the proprietor to act on his behalf. Thus, this user is approved by the registrar in respect of all or any of the goods which the proprietor registered either with or without conditions or restrictions (Section 33 and 34). At first glance, one might assume that this provision protects the interest of the proprietor fully. A closer look reveals that products carrying the trade mark lawfully placed on the market not by the proprietor or registered user would not be regarded as use by the proprietor (Section 33 (3)). Thus, this position presents a problem in that all users that are without the consent of the proprietor or that of the registered user do not amount to use.

As indicated already, and as required by Article 19.2 of the TRIPS Agreements where use by another person cannot be recognised as use under the law for the purpose of maintaining registration, the situation is very challenging in a country like Nigeria, especially, where a lot of importation is done from around the world by small business owners. For instance, there are no Louis Vuitton stores in Nigeria. However, a lot of people buy original Louis Vuitton bags to sell in Nigeria. Although, Louis Vuitton has not entered the Nigerian market, a lot of stores sell their genuine products which are unrelated to Louis Vuitton. The presumption is that Louis Vuitton can lose their right to the mark in Nigeria. This can only occur if the trade mark is registered, but is not used by the proprietor or the registered user.

Therefore, the requirement of the use of a trademark by another person to be recognised as the use of the trademark for the purpose of maintaining the registration is not complied with in section 33 (3) of the Trade Marks Act. Therefore, this Act recognises only the proprietor and the registered user.

\section{Parallel Imports}

Exceptions are very important part of any law. The broad nature of trade mark rights which are further extended by the continuous growth of new technologies and concepts has made the rights easily traversable without the owner's permission (Onyido, 2009). According to Article 17 of the TRIPS Agreement, members are expected to provide limited exceptions to trade mark rights. While the TRIPS Agreement did not state what limited 
exceptions consist of, a reasonable interpretation is expected to be given to it (UNCTAD/ICTSD, 2005). In the case of Canada Generic Pharmaceuticals, the Panel stated that the "term limited exception must be read to connote a narrow exception, one which makes only a small diminution of the rights in question."

Parallel imports refers to a situation in which genuinely branded product which has been purchased from the owner of the brand in country A either with a licence to sell to or manufacture in Country B has been imported into country $\mathrm{C}$. Thus, this is without the permission of the incumbent authorised licensee or has been imported into country A without the permission from the trade mark owner. These products may have been formulated or packaged differently for sale and are not intended for sale domestically in the markets of country A (INTA, 2012). Succinctly put, parallel importation involves the importation of goods also known as grey market goods, unconnected to the distribution channels negotiated and agreed upon contractually by the manufacturer (Hoekman \& Philip, 2002; Hiebert, 1994). Parallel imports are not counterfeited products. Thus, they are legitimate products authorised by the manufacturer (Correa, 2000; Mueller-Langer, 2008). Parallel imports can be profit driven and are usually sold at a lower price than similar goods in particular countries, which may be as a result of international pricing policies or currency differences (Trademark Owner's Guide, 2012).

According to Abbot, parallel importation is an economic issue which involves the necessary balance of interest between the consumers and the producers. His view is spot-on. Thus, he explains that consumers and producers have varied interests which have to be determined by the order of importance. He mentions that the interest of the consumer is a low price coupled with a quality product, availability of variety, and the support for the use of the product. On the other hand, the interest of the producer is solely to maximise his investment (Abbott, 1998).

Parallel importation has its legal basis in the doctrine of exhaustion of rights (Abbott, 2007). Generally, exhaustion of rights is regarded as a limitation on IPRs (WIPO). Notably, parallel importation has come to fore since the implementation of the TRIPS Agreement, especially in relation to patents. Although the TRIPS Agreement does not define parallel importation, nor exhaustion of rights, but cursorily mentions exhaustion of IPRs. This was mentioned in article 6. Firstly, it was in relation to dispute settlement under the TRIPS Agreement. Secondly, it entails providing only an implied approach for WTO members to follow in determining the structure of its exhaustion policy by making it subject to the provisions of articles 3 and 4 of the TRIPS Agreement. 
Exhaustion of rights refers to a situation where a product protected by IPRs has been put on the market by the manufacturer or with his consent. Subsequently, IPRs of commercial exploitation over this given product can no longer be exercised by the manufacturer. As a result, the right to monitor or prevent sales is deemed 'exhausted'. The reason for this principle is to maintain a balance between the public interest and the IPR owner (Slotboom, 2006). Generally, it is believed that this doctrine limits trademark owner's rights (Kobak, 2003). There are different forms of exhaustion of right. This form includes national, regional, and international exhaustion.

Nigeria has no provision on the exhaustion of rights and parallel importation in the trade marks law, neither does the Trade Mark Act or other laws, prohibit parallel imports. However, there is a regional provision on the doctrine of exhaustion which requires domestication for it to have the force of law in Nigeria (Article 5 Supplemental Act ECOWAS). Consequently, the absence of laws regulating exhaustion of rights and parallel importation has also led to the dearth of case law in this area.

Notably, there are two cases which emanated from the Federal High Court and went up to the Court of Appeal and Supreme Court. The cases point towards the issue of parallel importation and exhaustion of right.

The Honda Place Limited, Honda Motor Company Limited of Japan $v$ Globe Motors Holding Limited \& others: In this case, the appellant was a dealer appointed by the Japanese manufacturers of Honda cars, to import and market Honda cars in Nigeria. The appellant entered into a sub-dealership agreement with the respondent as a sub-dealer of Honda cars with the right to import and market $45 \%$ of cars allotted to the appellant by the Japanese manufacturer. Afterwards, a dispute arose between the parties in the operations of the sub-dealership agreement. This led to a spate of litigations. As a result, the suit was eventually settled out of court with the "Terms of Settlement" duly signed by all the parties. The terms of settlement were embodied in and became the judgment of the court.

In an earlier case, Honda Company Ltd and Another v Bright Motors and 4 others, an injunction was granted in favour of the claimant restraining the 'sale and importation of Honda products into Nigeria except through the authorised main dealer of Honda products in Nigeria'. The crux of the Honda case was the importation of Honda cars from the United States of America and the Middle East by Globe Motors Ltd into the Nigeria market. The Honda Place (THP) claimed that they had sole and exclusive distributorship of Honda cars into Nigeria, and that cars imported from the USA band the Middle East were ill-adapted for the Nigerian climate and market. They further argued that the importation was detrimental to THP, which has the license to distribute Honda cars in Nigeria. As such, they sought to protect their reputation and business. The defendants, on the other 
hand, contended that genuine goods imported 'from elsewhere outside Japan' did not alter the rights of the licensee. The court ordered the defendants to cease importing Honda cars from the United States or any other country except Japan.

These judgements favoured The Honda Place. Therefore, the question to be asked is should Honda Place be the only seller of Honda cars in Nigeria? Would this not amount to a sort of monopoly? Consequently, what the two judgements are driving at is unclear, and the issues are drowned in the sea of technicalities. What the various courts failed to note was that the agreement between The Honda Place Limited and Honda Motor Company Limited of Japan relates to the contractual agreement between the parties. Therefore, this does not in any way prevent other dealers from importing Honda cars from anywhere in the world. Section 5 of TMA grants a trade mark owner the exclusive right to use the trade mark in relation to the goods. This provision was used against the doctrine of exhaustion and parallel importation to prevent importation into Nigeria by any person other than the owner of the trade mark. As a result, they are restricting trade and, at the same time, encouraging monopoly.

In Japan where the cars emanated, the issue of parallel importation has been determined by case law and legislation. However, the Japanese through the Antimonopoly Act (AMA) clearly provides that any form of impediments to parallel imports contravene the law. Also, a trade mark is considered to be internationally exhausted once the product bearing the trade mark has been put on sale (Anderman, 2009). In fact, it was decided in the case of Parker that parallel imports should be permitted provided the goods are genuine, the trademark owner is identical, the quality of the imported goods is identical or substantially identical, and the goods imported do not affect the reputation of a trade marks owner. From these requirements, it is clear that this type of exclusive rights would not be tolerated in Japan.

In a country like Nigeria where the domestic manufacturing of goods is very low and imported goods make up most of the goods used, it is important that consumers are able to choose from a variety available to them. Thus, they are not limited by the law and bound to only one source. There are many international precedents on this issues which the court could have followed. In the European Union, Article 7 (1) modified by Annex 17 of the European Economic Area Agreement makes it clear that 'the trademark right shall not entitle the proprietor to prohibit its use in relation to goods which have been put on the market in a Community under that trade mark by the proprietor or with his consent'. The ECJ has decided several cases on exhaustion of trade marks such as Silhouette International Schwied GmbH \& Co KGU, Hartlauer Handelgesellschaft mbh. The Nigeria court could have taken these judgements into consideration in its decision to ameliorate the 
jurisprudential cessation on parallel importation and exhaustion of rights. Although foreign authorities cannot replace the case law, it may serve as a persuasive basis for determining the case. Thus, this was noted by the Supreme Court in Air Via Ltd. v Oriental Airlines Ltd.

In summary, the absence of a specific provision on parallel importation and exhaustion of rights in the Nigerian legislations gives judges the discretion to interpret section 5 as providing exclusive rights for the trademark owners to the detriment of consumers. Consumers are producers and producers are consumers. Therefore, a balance between the rights of the two is what the law should strive to provide.

\section{Conclusion}

The Nigeria Trade Marks Act has not been amended since 1967 despite the evolution of the different ways of trade marking. Nigeria as a country, with very high proliferation of consumer products, needs a trade mark legislation which is at breast with the recent international and national developments in the trade mark system. The trade marks legal framework seems deceptively simple. However, a closer examination reveals a lot of problems inherent in the framework which leaves numerous logical questions unanswered.

Concerning whether the Nigerian Trade Marks Act complies with the TRIPS Agreement as deduced from this examination, it is submitted that the required provisions on trade marks that were examined with regard to the TRIPS Agreement vary in their compliance with the TRIPS Agreement. Service marks are protected in compliance with the TRIPS Agreement. The issue of the absence of an express provision for the protection of well-known marks needs to be addressed. Also, proposed use required by the trade marks law is a vital aspect of a trade marks. Thus, it must be clarified by putting a system in place to determine such use.

Parallel imports and exhaustion of right are concepts that make the flow of trade easier. The absence of these concepts suggests some form of trade restriction, and accordingly, this provision needs to be amended to make provision for this exception. One issue that is clear and consistent among Nigerian scholars (Adewopo, 2002) is that the amendment of the law should take into cognisance the conditions in Nigeria when developing a model that suits the country.

\section{References:}

Abbot (2007). Parallel Importation: Economic and social welfare dimensions International. Institute for Sustainable Development Canada. Retrieved from http://ssrn.com/abstract=1915395 
Abbott (1998). First Report (final) to the Committee on International Trade Law of the International Law Association on the subject of parallel importation' Journal of International Economic Law (4) 607-636, 612 doi:10.1093/jiel/1.4.607.

Actes de La Haye, pp. 241/2, 246 (proposal), 341/3 (observations), 453/6 (report of Third Sub-Committee), 523 (report of General Committee), 543/4 (report of Drafting Committee), 577 (adoption in Second Plenary Session). P.455 cited in Bodenhausen G. H. C, (2007). Guide to the Application of the Paris Convention for the Protection of Industrial Property as Revised at Stockholm in 1967 Geneva: WIPO Publication N611 (E) BIRPI1969 007 Adewopo (2002). Intellectual Property law and Prospects for development. In T. Falola, \& A. O. Oyebade (Eds) The transformation of Nigeria: essays in Honour of Toyin Falola Erithea: African World Press Inc. Air Via Ltd. v Oriental Airlines Ltd. (2004) 9 N.W.L.R 298 AT 325.

Babafemi (2007). Intellectual Property. The Law and Practice of Copyright, Trade Marks, Patent and Industrial Design in Nigeria Ibadan: Justinian

Bently \& Sherman (2009). Intellectual Property Law (3rd ed.) Oxford: Oxford University Press

Bodenhausen (2007). Guide to the Application of the Paris Convention for the Protection of Industrial Property as Revised at Stockholm in 1967 Geneva: WIPO Publication N611 (E) BIRPI1969 007. Cananda Generic Pharmaceuticals para. 7.31 p. 155.

Chief J.E Oshevire v. British Caledonian Airways Ltd (1990) NWLR (Pt160) 507; See also

Colgate - Palmolive Ltd. \& Anor. v Markwell Finance \& Anor. [19891 R.P.C. 497. Trademark Owner's Guide to Parallel Imports in the United States Working with U.S. Customs and Border Protection to Prevent Importation of Gray Market Goods February 2012 INTA Publication retrieve from http://www.inta.org/Advocacy/Documents/INTA\%20Trademark\%20Owners \%20Guide\%20to\%20Parallel\%20Imports\%20in\%20the\%20United\%20State s.pdf Correa, C., (2000) Integrating Public Health Concerns into Patent Legislation in Developing Countries. Geneva: South Centre

Forsyth \& Rothnie (2009). Parallel Imports and Exhaustion. In S. Anderman (Ed) The Interface Between Intellectual Property Rights and Competition Policy Cambridge: Cambridge University Press

General Sanni Abacha v. Gani Fawehinmi [2001] 51 WRN 29 [2001] 51 WRN 29

Groves (1997). Intellectual Property Rights and Their Valuation: A Handbook for Bankers, Companies and their Advisers Cambridge: Woodhead Publishers 
Hiebert (1994). Parallel Importation in U.S. Trademark Law. Connecticut: Greenwood Press p.1; International Exhaustion and Parallel Importation retrieved from http://www.wipo.int/sme/en/ip_business/export/international_exhaustion.htm Hoekman \& Philip (Eds) (2002). Development Trade and the WTO: A Handbook, Volume 1 World Bank United Stated of America: Oxford University Press p.376;

Honda Company Ltd and Another v Bright Motors and 4 others, (1998) 12 NWLR Part 577

International Exhaustion and Parallel Importation retrieved from http://www.wipo.int/sme/en/ip_business/export/international_exhaustion.htm Joint Recommendation Concerning Provisions on the Protection of WellKnown Marks provides additional factors which may be used to determine if a mark is well-known retrieved from http://www.wipo.int/export/sites/www/aboutip/en/development_iplaw/pdf/pub833.pdf Jones (1996). Remedy Holes and Bottomless Rights: A Critique of the Intent-to-Use System of Trademark Registration' 59 Law and Contemporary Problems 2159

Kayode. The Growing Necessity for the Protection for Service Marks in Nigeria retrieved from at www.okayode.com/files/service_marks.pdf Kobak (2003). Exhaustion of Intellectual Property Rights and International Trade' Fordham University School of Law retrieved from at http://www.hugheshubbard.com/ArticleDocuments/Exhaustion_IP_Rights_2 003

Kur (2008). Fundamental Concerns in the Harmonization of (European) Trademark Law. In G. Dinwoodie \& M. Janis (Eds). Trade mark law and Theory, A hand book of Contemporary Research Cheltenham: Edward Elgar LADAS: "International Protection of Well-known Trade marks. To Trademark Reporter. 1951. p. 661; TROLLER: "La marque de haute renomm6e," P.I. 1953, p. 73; BLUM: "La marque de haute renomm6e. P.I" 1954, p. 110.cited in Bodenhausen G. H. C, (2007). Guide to the Application of the Paris Convention for the Protection of Industrial Property as Revised at Stockholm in 1967 Geneva: WIPO Publication Nº611 (E) BIRPI1969 007

Mao-Zong Haung (1995). Parallel imports, Intellectual Property and Fair Trade. In J. C Cheng, L. Liu, C. Wang (Eds.) International Harmonization of Competition Laws, The Netherlands: Marttinus Nijhoff Publishers

Mark Mordi (2011). Towards Trade Mark Law Reform in Nigeria: A Practitioner's Note' NIALS Journal of Intellectual Property [NJIP] Maiden Edition 19 
Matthew (2013). The Economist who invented the BRICs just invented a whole new group of countries: The MINTs Business Insider retrieved from http://www.businessinsider.com/jim-oneill-presents-the-mint-economies2013-11\#ixzz30HbZ17uD

McDonald's Corporation v Joburgers Drive-Inn Restaurant (Pty) Ltd. and Another (547/95) [1996] ZASCA 82; 1997 (1) SA 1 (SCA); [1996] 4 All SA 1 (A); (27 August 1996).

Mostert (1997). Famous and Well Known marks London: Butterworth

Mueller-Langer (2008). Does Parallel Trade Freedom Harm Consumers in Small Markets? 11 Croatian Economic Survey 11 retrieved from SSRN: http://ssrn.com/abstract=1885539 a

Oguamanam (1998). Trade Marks Trade Names Regime in Nigeria: The Momentum. In L. Fagbohun \& Adewopo (Eds). Development and Reforms in Nigeria Nigerian Commercial Law Lagos: Law Center LASU

Okorocha (2007). Nigeria Introduces Service Marks INTA Bulletin September 1, Vol. 62 No. 16 retrieve from http://www.inta.org/INTABulletin/Pages/NigeriaIntroducesServiceMarks.as $\mathrm{px}$

Oloruntoba-Oju v. Dopamu, [2008] All FWLR [Pt 411] 810 per Oguntade JSC

Onyido, J. Making a Case for the Trademark Misuse Doctrine retrieve from http://www.spaajibade.com/admintoolnew/uploads/making_a_case_for_the_t rademark_misuse_doctrine-2spaaco.pdf

Oyebode (2003). Treaty Making and Treaty Implementation in Nigeria: An Appraisal Ikeja Lagos: Bolabay Publications

Oyewunmi (2007). Industrial Property Law. In E. O Akanki (Ed), Commercial Law in Nigeria Lagos: University of Lagos Press Pangariya, A. (2004). Critical Perspective on the Global Trading System and the WTO. In K. Maskus (Ed), The WTO, Intellectual Property Rights and the Knowledge Economy TRIPS and the WTO: An Uneasy Marriage, Cheltenham: Elgar

Recital 9 of the Harmonisation Directive 2009/25

Reiss, S. M. Commentary on the Paris Convention for the Protection of Industrial Property retrieved from http://www.lex-ip.com/Paris.pdf

Shyllon (2003). Intellectual property Law in Nigeria. Munich: Max Planck Institute for Intellectual Property, Competition and Tax Law

Sikoyo, Nyukuri \& Wakhungu (2006). Intellectual Property Protection in Africa Status of Laws, Research and Policy Analysis in Ghana, Kenya, Nigeria, South Africa and Uganda Kenya: African Centre for Technology Studies (ACTS) Press, Ecopolicy Series no. 16

Silhouette International Schwied GmbH \& Co KGU. Hartlauer Handelgesellschaft mbh. CJ, 16 July, 1998, Case C-355/96 
Slotboom (2006). A Comparison of WTO and EC Law: Do Different Objectives and Purposes Matter for Treaty Interpretation London: Cameron May

Smyth (2010). A Crowded CTM Register' European Community Trade Marks Association 29 annual Conference June 19- 2010 retrieved from http://www.ecta.org/IMG/pdf/full_textsmyth_letterhead.pdf

Sodipo (1997). Piracy and Counterfeiting GATT and Developing Countries London: Kluwer Law International

Stoll, Busche \& Arend (Eds) (2009). WTO-Trade related aspects of Intellectual Property Rights Max Planck Commentaries on World Trade Law (Vol 7) The Netherlands: Martinus Nijhoff Publishers

Supplemental Act Adopting Community Competition Rules and the Modalities for their Application within ECOWAS.

Taiwo (2009). IP Law in Nigeria: New Trends and Challenges in INSIDE THE MIND IP Client Strategies in the Middle East and Africa Leading Lawyers on Understanding Recent Developments and Proposed Changes, Managing Client Expectations, and Recognising Regional Influences on Intellectual Property Law. Lagos: Aspatore books

Taubman (2011). A Practical Guide to Working with TRIPS. Oxford: Oxford University Press

The Honda Place Limited, Honda Motor Company Limited of Japan $v$ Globe Motors Holding Limited \& others FHC/L/CS/1442/97; -SC.161/2001.

The Intellectual Property Office (IPO) (2012). Trade Mark Cluttering: An Exploratory Report retrieve from http://www.ipo.gov.uk/ipresearchtmcluttering.pdf

UNCTAD-ICTSD (2005). UNCTAD Resource Book on TRIPS and Development New York: Cambridge University Press

Working Paper on the Reform of Industrial Property Law (Nigeria Law Reform Commission) 1990np.153 para 247.

Workshop on the Revision of Trademark Law, Diqing (Yunnan Province), P.R. China from 13 to 15 May 2010 available Danish Patent and Trademark Office retrieve from http://www.ipr2.org/storage/RavnWhat_is_a_defensive_mark-EN1030.pdf

World Bank Report: Africa's Pulse APRIL 2014 | VOLUME 9 retrieved from

http://www.worldbank.org/content/dam/Worldbank/document/Africa/Report/ Africas-Pulse-brochure_Vol9.pdf

$\mathrm{Yu}$ (2007). 'Intellectual Property Rulemaking in the Global Capitalist Economy, The International Enclosure Movement' Indiana Law Journal 82 Yu (2009). World intellectual Property Organisation Journal 1(8) 